\title{
Cytotoxic activity of crude extracts of Bacteroides gingivalis
}

\author{
P. I. EKE, B. E. LAUGHON* and V. O. ROTIMIt
}

Department of Medical Microbiology, College of Medicine, P.M.B. 12003, Lagos, Nigeria and *Division of Infectious Diseases, Johns Hopkins Hospital, Blalock 1111, Baltimore, MD 21205, USA

\begin{abstract}
Summary. The cytotoxic activities of culture supernates, crude cell extracts and cellwall materials of Bacteroides gingivalis were investigated in vitro. Each component was cytotoxic to Vero cells and, to a lesser extent, Wi 38 cells. The cytotoxic agents had similar effects on the cell lines to butyric acid, propionic acid and a partiallypurified trypsin-like protein extracted from a clinical isolate of $B$. gingivalis; the effects were eliminated by heat. Cytotoxic materials obtained from young cultures were more susceptible to heat than those from older cultures. The heat-labile substance inside and outside the bacterial cell in young cultures of $B$. gingivalis may contribute to its overall cytotoxic activity.
\end{abstract}

\section{Introduction}

The production of cytotoxins that affect soft and hard tissues is common amongst some oral pathogens, including Actinomyces, Fusobacterium and black pigmented Bacteroides species. Among the pigmented bacteroides, only Bacteroides gingivalis produces cytotoxins to chondrocytes and Vero (African green monkey kidney) cells in vitro (Touw et al., 1982a). This activity has been associated with butyrate and propionate by-products of amino-acid metabolism (Van Steenbergen et al., 1982; Grenier and Mayrand, 1985). It is not certain if these fatty acids are solely responsible for the cytotoxic activities of $B$. gingivalis in vitro, because B. asaccharolyticus, a closely-related species which also produces butyric and propionic acids, does not induce a cytopathic effect on similar cell lines (Grenier and Mayrand, 1985).

$B$. gingivalis has been separated from B. asaccharolyticus (Coykendell et al., 1980) and two important differences between these species are the production by $\boldsymbol{B}$. gingivalis of (i) a proteolytic enzyme resembling trypsin and (ii) phenylacetic acid as a metabolic end product (Laughon et al., 1982; Mayrand and Bourgeau, 1982). This study sought to determine whether substances other than butyric and propionic acids produced by $B$. gingivalis participate in its cytotoxic activity.

Received 5 May 1988; revised version accepted June 1988

$\dagger$ Requests for offprints should be sent to Professor V. O. Rotimi, Medical Microbiology and Parasitology Department, College of Medicine, University of Lagos, P.M.B. 12003, Lagos, Nigeria.

\section{Materials and methods}

\section{Bacteria}

Strains of $B$. gingivalis isolated from oral infections were used; strains isolated from clinical specimens in Lagos University Teaching Hospital were designated "Nig" 1, 2, 7 and 10, and a strain obtained from $\mathrm{Dr}$ Martin, Maryland University Dental School, CS 43. A reference strain, B. gingivalis ATCC 33277 , was also studied. All strains were previously characterised by tests that included enzymatic and chromatographic profiles and they were identified according to Bergey's Manual of Systematic Bacteriology (Holdeman et al., 1984) and Sutter et al. (1985).

\section{Cell lines}

Vero cells and Wi 38 (human lung fibroblast) cells were used in this study. Cell lines were prepared and maintained by standard methods $; 0.1 \mathrm{ml}$ of a suspension containing $c .1-2 \times 10^{5}$ cells $/ \mathrm{ml}$ in Eagle's Minimum Essential Medium (MEM) with fetal calf serum (FCS; Flow Laboratories) $10 \%$ was added to wells in tissueculture plates (Falcon 3072, Becton Dickinson Laboratories) and incubated in air $+\mathrm{CO}_{2} 5 \%$ at $37^{\circ} \mathrm{C}$ for $48 \mathrm{~h}$; wells with confluent growth of cells that completely covered the well bottom were selected for use.

\section{Culture supernates}

B. gingivalis cultures in Brain Heart Infusion Broth with supplement (BHIS ; Scott Laboratories) were centrifuged at $15000 \mathrm{rpm}$ for $15 \mathrm{~min}$; the supernates were collected and then sterilised by passing through a $0 \cdot 22-$ $\mu \mathrm{m}$ Nalgene membrane filter (Nalge Co., Rochester, NY). Further dilutions of the supernates were made in 
sterile MEM without FCS. One batch of culture supernates was heated in sealed tubes at $60^{\circ} \mathrm{C}$ for $30 \mathrm{~min}$ to inactivate proteolytic enzymes; heating in a closed system ensured that volatile acids were retained.

\section{Crude cell extracts}

Each test strain of $B$. gingivalis was grown in $1 \mathrm{~L}$ of BHIS for $72 \mathrm{~h}$. Cells were harvested by centrifugation as above and washed twice in phosphate buffered saline (PBS, pH 7.2). The washed pellet was crushed with sterile beads in a bead beaker on ice. A crude extract from the cells was separated from the cell-wall debris by high speed centrifugation at $15000 \mathrm{rpm}$ for $45 \mathrm{~min}$ at $4^{\circ} \mathrm{C}$. The supernate (lysate) was carefully decanted. This and the cell-wall materials were stored at $4^{\circ} \mathrm{C}$ for no longer than 1 week. Partially purified trypsin-like protease (PPTP) of $B$. gingivalis, previously prepared by the above method and then extracted by gel filtration (Dr Barbara Laughon, Johns Hopkins Hospital, Baltimore, MD) was used for comparison in the cytotoxicity-assay experiments. The specific trypsin-like activity (activity/mg of protein $/ \mathrm{ml}$ ) of the crude extract (lysate) was determined by hydrolysis of the chromogenic enzyme substrate $\mathrm{N}$-x-benzoly-DL-arginine-p-nitroaniline $\mathrm{HCl}$ (BAPNA) (Laughon et al., 1982). The trypsin-like activity of the extract (lysate) was measured in a Spectronic 21 spectrophotometer (Bausch and Lomb Inc., Philadelphia, PA) as the amount, in units of chromogen released from the substrate/min, measured by the intensity of colour change.

\section{Organic acids}

Serial dilutions of propionic, $n$-butyric and phenylacetic acids were made in MEM (without FCS) and adjusted to $\mathrm{pH} 7.2$ before filter-sterilisation. Each of these organic acids was diluted to give ranges of final concentrations of $6 \cdot 0-100 \mathrm{mM}$.

\section{Cytotoxicity assay}

Growth medium was removed by suction from wells with confluent cell growth and replaced with serial dilutions (neat to 1 in 8 ) of culture filtrates, fatty acids, crude cell lysates, cell-wall materials or PPTP (the protein extracts with high trypsin-like activities). Cell culture was then incubated at $37^{\circ} \mathrm{C}$ in air $+\mathrm{CO}_{2} 5 \%$ for $48 \mathrm{~h}$. Cytotoxicity was then assessed as follows: +++ cytotoxic to $\geqslant 90 \%$ of cells; + + cytotoxic to $50-90 \%$, and +cytotoxic to $<50 \%$ of cells; - indicated no cytotoxic activity. Each assay was performed in triplicate and the viability of cells was determined by the uptake of a 1 in 6 dilution of $0.4 \%$ trypan blue.

\section{Results}

Experimental results showed that Vero cells were more sensitive than Wi 38 cells to the cytotoxic activity of the various bacterial components. A 1 in 4 dilution of culture filtrates was toxic to $>50 \%$ of Vero cells but cytotoxic activity was scarcely seen in the Wi 38 cells at this dilution. A 1 in 8 dilution of the crude cell extracts was cytotoxic to $>90 \%$ of Vero cells but not to Wi 38 cells. In Vero cells, the cytotoxic activity of the crude extracts was more pronounced than the effect produced by a similar dilution of filter-sterilised culture supernates.

Unheated and some heated culture supernates were cytotoxic to Vero cells in vitro. Generally, unheated supernates produced a more severe cytotoxic effect on the Vero cells than heated supernates, which was demonstrated by the lack of cytotoxic effect of the heated supernates at a dilution of 1 in 8 (table I). The effect of heat on the cytotoxic activity of the various preparations was more pronounced with the crude cell lysates. Whereas unheated cell lysates were cytotoxic for $>$ $90 \%$ of Vero cells at a dilution of 1 in 4 , only the neat heated lysates produced appreciable effects on Vero cells. Heat treatment reduced the cytotoxic activity of supernates and crude cell lysates of all the $B$.gingivalis strains suggesting that a heatsensitive substance, probably a protein, is also involved in the overall cytotoxic activity of $B$. gingivalis. When supernate from a 5-day-old broth culture was used for the assay, a more severe cytotoxic effect than found with the 72 -h old supernates was observed on the Vero cells; the 5day-old supernate was also less susceptible to the effect of heat.

The fatty acids, i.e., butyric, propionic and phenylacetic acids, produced various degrees of cytotoxicity on Vero cells. Propionic acid was cytotoxic at $12.5 \mathrm{~mm}$ to $>90 \%$ of Vero cells whereas only at a concentration of $50 \mathrm{mM}$ was it cytotoxic to Wi 38 cells. As low as $6.0 \mathrm{~mm}$ butyric acid was cytotoxic to $50 \%$ of Vero cells and Wi 38 cells. Phenylacetic acid was the least cytotoxic to the Vero and Wi 38 cell lines, producing only a weak cytopathic effect on Vero cells and Wi 38 cells at $50 \mathrm{~mm}$ and $100 \mathrm{~mm}$ respectively.

The cytotoxic activity of the cell extracts was identical with that of the control PPTP; similar high trypsin-like activity was demonstrated in the cell extracts by spectrophotometry. The substance in the cell extract responsible for the toxic effect was found to be a protein. Table II shows the cytotoxic activity of the extracts on Vero cells. Extracts with specific trypsin-like activity of 10 units $/ \mathrm{mg} / \mathrm{ml}$ were cytotoxic to $90 \%$ of Vero cells in vitro but, when heated, cytotoxic activity was completely lost. Similarly, cell-wall components diluted 1 in 6 were cytotoxic for Vero cells, a 
Table I. The cytotoxic effects of culture supernates and crude cell lysates on Vero cell lines

\begin{tabular}{|c|c|c|c|c|}
\hline \multirow{2}{*}{$\begin{array}{l}\text { B. gingivalis } \\
\text { preparations }\end{array}$} & \multicolumn{4}{|c|}{ Cytotoxicity score at dilutions } \\
\hline & Neat & 1 in 2 & 1 in 4 & 1 in 8 \\
\hline \multicolumn{5}{|l|}{ Unheated supernate } \\
\hline ATCC 33277 & ++ & ++ & + & + \\
\hline Nig 1 & ++ & ++ & + & + \\
\hline Nig 2 & ++ & ++ & + & + \\
\hline Nig 7 & ++ & ++ & + & + \\
\hline Nig 10 & ++ & ++ & + & + \\
\hline CS 43 & ++ & ++ & + & + \\
\hline \multicolumn{5}{|l|}{ Heated supernate } \\
\hline ATCC 33277 & ++ & ++ & + & - \\
\hline Nig 1 & ++ & ++ & + & - \\
\hline $\mathrm{Nig} 2$ & ++ & ++ & + & - \\
\hline Nig 7 & ++ & ++ & + & - \\
\hline Nig 10 & ++ & ++ & + & - \\
\hline $\mathrm{CS} 43$ & ++ & $+t$ & + & - \\
\hline \multicolumn{5}{|l|}{ Unheated cell lysate } \\
\hline ATCC 33277 & $+t+$ & +++ & +++ & + \\
\hline Nig 1 & +++ & +++ & $++t$ & + \\
\hline Nig 2 & +++ & +++ & +++ & + \\
\hline $\mathrm{Nig} 7$ & +++ & +++ & ++ & + \\
\hline $\mathrm{Nig} 10$ & $+t+$ & +++ & ++ & + \\
\hline CS 43 & $++t$ & +++ & ++ & + \\
\hline \multicolumn{5}{|l|}{ Heated cell lysate } \\
\hline ATCC 33277 & + & - & - & - \\
\hline Nig 1 & - & - & - & - \\
\hline Nig 2 & - & - & - & - \\
\hline Nig 7 & + & - & - & - \\
\hline Nig 10 & - & - & - & - \\
\hline CS 43 & + & - & - & - \\
\hline \multicolumn{5}{|c|}{$\begin{array}{l}\text { Unheated cell-wall pre- } \\
\text { cipitates }\end{array}$} \\
\hline ATCC 33277 & ++ & ++ & ++ & + \\
\hline Nig 1 & ++ & $+t$ & ++ & + \\
\hline Nig 2 & ++ & ++ & ++ & + \\
\hline Nig 7 & ++ & ++ & ++ & + \\
\hline Nig 10 & ++ & ++ & ++ & + \\
\hline \multicolumn{5}{|c|}{$\begin{array}{l}\text { Heated cell-wall precip- } \\
\text { itate }\end{array}$} \\
\hline ATCC 33277 & + & - & - & - \\
\hline Nig 1 & + & - & - & - \\
\hline Nig 2 & ++ & - & - & - \\
\hline Nig 7 & ++ & - & - & - \\
\hline Nig 10 & ++ & - & - & - \\
\hline $\operatorname{CS} 43$ & ++ & - & - & - \\
\hline
\end{tabular}

$\mathrm{Nig}=$ Nigerian strains

$\mathrm{CS}=$ hospital strain (Maryland University Dental Hospital).

property lost after heating. Detachment of all the cells was characteristic of the cytotoxic activities of the protein extracts, the cell wall component, and the control PPTP.
Table II. Cytotoxic effects on Vero cells of different cell materials with trypsin-like activity

\begin{tabular}{|c|c|c|c|c|c|}
\hline \multirow[b]{2}{*}{ Cell-wall component } & \multicolumn{5}{|c|}{$\begin{array}{l}\text { Specific cytotoxic activity at } \\
\text { (units/mg of protein } / \mathrm{ml} \text { ) }\end{array}$} \\
\hline & 100 & 50 & 20 & 10 & 25 \\
\hline $\begin{array}{l}\text { PPTP } \\
\text { unheated } \\
\text { heated }\end{array}$ & $\begin{array}{c}++ \\
-\end{array}$ & $\begin{array}{c}++ \\
-\end{array}$ & $+t+$ & $\begin{array}{c}++ \\
-\end{array}$ & $\begin{array}{l}+ \\
-\end{array}$ \\
\hline $\begin{array}{l}\text { Crude cell lysate } \\
\text { unheated } \\
\text { heated }\end{array}$ & $\begin{array}{c}++ \\
-\end{array}$ & $\begin{array}{c}++ \\
-\end{array}$ & $\begin{array}{c}++ \\
-\end{array}$ & $\begin{array}{c}++ \\
-\end{array}$ & + \\
\hline
\end{tabular}

PPTP $=$ partially purified trypsin-like protease.

\section{Discussion}

Data presented in this study show that culture filtrates and crude cell lysates of $B$. gingivalis contain substances that are cytotoxic to Vero cells and, to a lesser extent, Wi 38 cells. Cytotoxic activities of $B$. gingivalis have been reported by Van Steenbergen et al. (1982), and Grenier and Mayrand (1985). Their reports and those of Touw et al. (1982b) implicated butyric and propionic acids as the components responsible for the cytotoxic activities of B. gingivalis. Relatively low concentrations of butyric and propionic acids were cytotoxic to Vero cells and Wi 38 cells in vitro. Studies by Touw et al. (1982b) and Grenier and Mayrand (1985) have shown that the cytotoxic activity in Vero cell lines is peculiar to $B$. gingivalis amongst the asaccharolytic pigmented bacteroides, even though some other members of this group are known to produce butyric and propionic acids, e.g., B. asaccharolyticus produces more propionic acid but less butyric acid than $B$. gingivalis, but does not produce cytotoxic activity with either of the cell lines (Grenier and Mayrand, 1985; Touw et al., 1982b).

$B$. gingivalis characteristically produces phenylacetic acid, which in this study produced a very weak cytotoxic effect; this observation is in agreement with the findings of Grenier and Mayrand (1985). The cytotoxic activities of the culture filtrates and the cell lysates of $B$. gingivalis were more pronounced than those of the fatty acids, indicating that substances other than fatty acids, may also be involved in the production of the cytotoxic effects on the cell lines. The substance is both intracellular and extracellular, although it appeared to be more concentrated inside the cell. Both the culture filtrates and the cell lysates 
produced cytotoxic effects identical to those of PPTP. The activity of the crude cell lysates was similar to that of PPTP with respect to heat sensitivity and trypsin-like activity as measured by spectrophotometry.

Volatile fatty acids are extracellular products of amino-acid metabolism and are not present in significant amounts in crude cell lysates from washed cells of $\boldsymbol{B}$. gingivalis. Furthermore, they are not susceptible to heat; thus the reduced cytotoxic effect of heated culture filtrates and crude cell lysates could not be attributed to the presence of these fatty acids. It was apparent that the enhanced cytotoxicity of the unheated materials from $B$. gingivalis was due to an additional substance present in the cell culture. The cell-wall materials and cell lysates produced the same pattern of cytotoxicity as PPTP. These were completely

\section{REFERENCES}

Coykendell A L, Kaczmarek F S, Slots J 1980 Genetic heterogenicity in Bacteroides asaccharolyticus (Holdeman and Moore 1970) Finegold and Barnes 1977 (Approved lists, 1980) and proposal of Bacteroides gingivalis sp nov. and Bacteroides macacae (Slots and Genco), comb. nov. International Journal of Systematic Bacteriology 30 : 559-564.

Grenier D, Mayrand D 1985 Cytotoxic effect of culture supernatants of oral bacteria and various organic acids on Vero cells. Canadian Journal of Microbiology 31 : 302-304.

Holdeman L V, Kelley R W, Moore W E C 1984 Bacteroidaceae. In: Krieg N R, Holt J G (eds) Bergey's Manual of systematic bacteriology, 9th edn. Williams and Wilkins, Baltimore, $\mathrm{MD}, \mathrm{p} 602$.

Laughon B E, Syed S A, Loesche W J 1982 Rapid identification of Bacteroides gingivalis. Journal of Clinical Microbiology 15 : $345-346$.

Mayrand D, Bourgeau G 1982 Production of phenylacetic acid by anaerobes. Journal of Clinical Microbiology 16:747-750. eliminated by heat, suggesting that the substance in these materials is also a protein with the trypsinlike activity of PPTP (Laughon et al., 1982). Other proteolytic enzymes produced by $\boldsymbol{B}$. gingivalis, such as collagenase, are also produced by some other pigmented bacteroides, e.g., B. intermedius, which have no apparent cytotoxic properties.

The data presented in this study confirm the cytotoxic activity of crude culture filtrates and cell lysates of $B$. gingivalis and show that a substance(s) resembling a proteolytic enzyme such as trypsin is an important cytotoxic agent in substances obtained from B. gingivalis. The cytotoxic properties of a proteolytic enzyme with trypsin-like activity has not been previously reported and it may play an important role in the pathogenesis of soft-tissue infections caused by $B$. gingivalis.

Sutter V L, Citron D M, Edelstein M A C, Finegold S M 1985 Wadsworth anaerobic bacteriology manual, 4th edn. Star Publishing Co., Belmont, CA.

Touw J J A, Van Kampen G P J, Van Steenbergen T J M, Veldhuiszen J P, De Graaff J $1982 a$ The effect of culture filtrate of oral strains of black-pigmented bacteroides on the matrix production of chick embryo cartilage in vitro. Journal of Periodontal Research 17:351-357.

Touw J J A, Van Steenbergen T J M, De Graaff J $1982 b$ Butyrate: A cytotoxin for Vero cells produced by Bacteroides gingivalis and Bacteroides asaccharolyticus. Antonie Van Leeuwenhoelk 48: 315-325.

Van Steenbergen T J M, Den Ouden M D, Touw J J A, De Graaff J 1982 Cytotoxic activity of Bacteroides gingivalis and Bacteroides asaccharolyticus. Journal of Medical Microbiology 15 : 253-258. 